\title{
BETWEEN AMBIVALENCE AND NECESSITY IN THE NILE BASIN:

\author{
OcClusions ON THE PATH TOWARDS A BASIN-WIDE TREATY
}

\author{
Takele Soboka Bulto *
}

\begin{abstract}
"Watersheds come in families; nested levels of intimacy. On the grandest scale the hydrologic web is like all humanity. ... The big river is like your nation, a little out of hand. The lake is your cousin. The creek is your sister. The pond is her child. And, for better or worse, in sickness and in health, you are married to your sink." 1
\end{abstract}

\section{Introduction}

Basin-wide arrangements such as the Nile Basin Initiative (NBI) ${ }^{2}$ are crucial to regulate specific regional problems. ${ }^{3}$ If effective, they are better placed to address the special peculiarities of a given hydropolitical region than are the general rules of international law. ${ }^{4}$ Conversely, general rules of international law could provide a general framework for basin states that need to negotiate the modus operandi of their respective access to common waters like the

* LL.B (AAU), LL.M (UP), M.A (AAU), PhD Candidate, Melbourne Law School, The University of Melbourne, Australia. I wish to acknowledge with gratitude the sustained intellectual stimulation and encouragement of Ato Elias Nour, who not only closely followed up the progress of this article right from its inception through its completion, but also gave me his illuminating comments on an earlier version of this paper.

${ }^{1}$ Michael Parfit, quoted in Maude Barlow, and Tony Clarke, Blue Gold: The Battle against Corporate Theft of the World's Water (2002) xi.

2 Launched in February 1999 in Dar Es Salaam, Tanzania, with all the Nile riparian but Eritrea as members, the NBI is a temporary mechanism through which the basin states would establish a basin wide treaty and institutional mechanism for the equitable and reasonable sharing of the common waters. It is expected to draft a basin-wide treaty binding upon all riparian states that establishes a Nile Basin Commission with powers to study and resolve conflicts over the utilization of the Nile waters. It operates from its head quarters in Kampala, Uganda.

Basin-specific treaties complement and supplement the general rules of international law regulating the use of international watercourses. In cases of conflict between the two sets of rules, the basinwide treaty prevails through the legal maxim that special rules prevail over the general (lex spacaialis rule) and the general rules give way to the special ones on the particular subject. See Philippe Sands, 'Watercourses, Environment and 
Nile. ${ }^{5}$ As Hayward observed, 'a clear view of the requirements of international law can provide States with a reference point from which to assimilate the diverse influences that shape their actions and interactions with their riparian neighbours' ${ }^{6}$ It is in the same vein that Art 3 of the 1997 UN Convention on Non-Navigational Uses of International Watercourses (Watercourse Convention) ${ }^{7}$ is worded in such a manner that recognizes 'the "framework" nature of the [Watercourse] Convention...[and it] encourages parties to follow the general principles on the Convention in their specific agreements without preventing them from departing from it. ${ }^{8}$

Yet, in the regulation of inter-state right and duties over common waters, international law generally leaves much to be desired. Attempts to develop and elaborate rules of international law pertaining to the regulation of a state's right to utilization and management of international waters have been met only with a modest success in terms of codifying binding and universally applicable rules. It has been observed that '[i]nternational river law is one of the most unsettled areas of international law; it is an area where there are few rules of general application or validity. 9 The only convention that purports to have the potential of universal applicability in the regulation of inter-state non-navigational utilization of international waters to date is the Watercourse

the International Court of Justice: The Gabcikovo-Nagymaros Case' in Salman M. A Salman, Boisson de Chazournes, Laurence (ed), International Watercourses: Enhancing Cooperation and Managing Conflict: Proceedings of a World Bank Seminar (1998) 121.

${ }^{4}$ See R D Hayton, 'The Formation of the Customary Rules of International Drainage Basin Law ' in A H Garretson, R D Hayton and C J Olmstead (ed), The Law of International Drainage Basins (1967) 862.

${ }^{5}$ See Stephen C. McCaffrey, 'A Human Right to Water: Domestic and International Implications' (1992) 5(1) The Georgetown International Environmental Law Review 18.

${ }^{6}$ Keith Hayward, 'Supplying Basin-Wide Reforms with an Independent Assessment Applying International Water Law: Case Study of the Dnieper River' (2007)
18(3) Colorado Journal of International Environmental Law and Policy 633.

Convention on the Law of the Nonnavigational Uses of International Watercourses 1997; Adopted by the General Assembly of the United Nations on 21 May 1997. The adoption of the Convention saw 103 states voting in favour, 3 against (Burundi, China and Turkey) and 27 abstain against it. See General Assembly resolution 51/229, annex, Official Records of the General Assembly, Fiftyfirst Session, Supplement No. 49, (A/51/49); available at <http:// untreaty.un.org/ilc/texts /instruments/ english/ conventions /8_3 1997.pdf >, last accessed 06 February 2008.

${ }^{8}$ Stephen C McCaffrey, and Mpazi Sinjela, 'The 1997 United Nations Convention on International Watercourses' (1998) 92(1) The American Journal of International Law 98. See also Arts 3 and 4 of the Watercourse Convention. 
Convention which has yet to enter into force as it is awaiting the necessary trigger- ratification. ${ }^{10}$

Various general rules of international law require specific basin or sub-basin agreements for their application. In effect, the regulation of a state's right to access the waters of an international river such as the Nile has been left to the bilateral or multilateral agreements among the riparians of a given water. In the Nile Basin, such a regulatory framework is expected to result from the efforts of the NBI. Obviously, to date the NBI framework is more of a promise than an achievement as it has yet to establish a basin-wide treaty and the Nile Basin Commission.

In the basin that has seen much more of discordance, unilateralism, mutual insecurity and suspicion as well as conflicts among the riparians rather than trust and cooperation, the establishment of the NBI in itself has appeared to throw up a beacon of light. A new dawn of rapprochement seemed to be on the horizon when the Nile riparian states declared that 'there is no regional or international treaty or agreement among the riparian States of the Nile River Basin... on cooperation in the utilization of the waters of the Nile River Basin. ${ }^{11}$ This declaration is of crucial significance as it marked, prima facie, a break away from the hitherto prevailing stance of some riparian (notably Egypt and Sudan) that insisted on the continued validity of some colonial and postcolonial treaties and their extended application to non-state parties of the Nile Basin riparian. Although Egypt and Sudan did not expressly renounce the validity of the status quo, the embodiment of the principle of equitable utilization of the Nile in NBI's declaration implies a departure from the status quo which did not recognize the equitable share of upstream riparians.

Yet there seemed to be a retreat from this stance and an apparent change of heart among the lower riparians. Of late, Egypt and Sudan have come up with the proposition that the status quo of the existing uses be respected, in a manner that adversely affects the interests of upper riparians. The official reason for this change of stance has been attributed to the two downstream states' fear of possible threat to 'their water security', who proposed to insert a clause in the draft instrument for the maintenance of the same. According to the Chair of the Nile Council of Ministers, Egypt and Sudan have insisted on the recognition by the other Nile riparians of the 1929 treaty between the UK

\footnotetext{
${ }^{9}$ Yimer Fisseha, 'State Succession and the ${ }^{10}$ Thirty-five states should ratify the ConLegal Status of International Rivers' in vention for it to come into operation. See Ralph Zacklin, et. al. (ed), The Legal Regime of International Rivers and Lakes (1981) 177. Watercourse Convention, Art. 36 (1) and (2).

${ }^{11}$ See Nile Basin Initiative Act (2002), Preamble, Para 2.
} 
(acting on behalf of Sudan) and Egypt. ${ }^{12}$ Where the situation stands now, the move towards basin-wide framework and the establishment of the Nile Basin Commission within the NBI has hit a temporary glitch, casting doubt over the immediate prospect of reaching a final framework agreement over utilization, management and protection of the waters of the Nile. Such an attitude, it will be shown, is never an isolated incident, as similar motives and actions have provided roadblocks to the conclusion of an agreement over the equitable sharing of the Nile waters over the past decades.

This paper argues that three barriers must be overcome for the ongoing NBI efforts to take off the ground: legal paucity, obsession with history and doctrinal wranglings. In the next three sections, the paper grapples with these three barriers in that particular order. In the two sections that follow, the role of basin-specific arrangements and the special role of the NBI will be presented. It will be argued that states have the duty to negotiate in good faith to reach basin-wide agreements. Finally, conclusions and brief recommendatory notes have been forwarded.

\section{The State of International Law Regulating Inter-state Water Rights}

Analysis of the rules of international law over the management, utilisation and development of transboundary river basins such as the Nile leave one in a penumbra of doubt as to whether there are specific rules capable of resolving the apportionment of the shared waters. Apart from the Watercourse Convention which is yet to become operational after the necessary number of ratifications, rules of international water law have 'always been (and remain [..]) vague and uncertain. ${ }^{13}$ Except for a few principles such as the principles of equitable utilisation, the no-significant harm rule, and the duty to negotiate in good faith that emerge from customary rules (see section 6 below), general

12 Joseph Ngome, Daily Nation, "News Extra: Clause Holds Key to New Nile Treaty', Nairobi, Kenya, 28 March 2008; available at <Nationmedia_com>, last accessed 28 March 2008. Information pertaining to the negotiation process and its progresses are hardly available as the dialogue is surrounded by a cult of secrecy.

${ }^{13}$ See Lucius Caflisch, 'Regulation of Uses of International Watercourses' in Salman M. A Salman, Boisson de Chazournes, Laurence (ed), International Water- courses: Enhancing Cooperation and Managing Conflict: Proceedings of a World Bank Seminar (1998) 316; Ellen Hey, 'Sustainable Use of Shared Water Resources: The Need for a Paradigm Shift in International Watercourses Law' in Gerald H Blake, et. al. (ed), The Peaceful Management of Transboundary Resources (1995) 127-130; Dante A Caponera, 'Shared Waters and International Law' in Gerald $\mathrm{H}$ Blake, et. al. (ed), The Peaceful Management of Transboundary Resources (1995) 121123. 
positive international law has to travel a long distance before declaring itself ready and able to regulate inter-riparian allocation of water resources .

This lacuna points to the heightened importance of basin-specific treaties and mechanisms that should be installed. For example, the basin states of the Niger, the Senegal, the Zambezi river basins and the SADC Protocol have treaties and mechanisms to enforce cooperation among the riparians. In contrast, the Nile Basin States have not entered into any formal permanent arrangements concerning their dividend from their shared water. ${ }^{14}$ Saving the dual exceptions of the 1929 and the 1959 treaties between Sudan and Egypt, all the bi-lateral and multilateral agreements over the waters of the Nile failed to apportion the bounty of the river among the riparians. ${ }^{15}$ Almost all of the colonial treaties were concluded with the sole aim of freezing upstream projects over the Nile, in order to secure a continuous and undiminished flow of the water to Egypt. Consensus now exists that colonial agreements over the Nile have no legal effect whatsoever. ${ }^{16}$

There has never been a treaty that has brought together all the riparians of the Nile. It is indubitable that "currently, there is no regional or international Treaty or Agreement among the riparian States of the Nile River Basin. ${ }^{\text {,1 }}$ This has left the basin without any comprehensive regulatory framework wherein an anarchic situation looms large, a scenario that inevitably perpetuates the hitherto prevailing unilateralism. Thus, the ongoing negotiation is all too important for the purpose of establishing a cooperative atmosphere in a basin where unilateralism, inter-state competition and mutual suspicion have been the norm while joint management and cooperation over the common resource have been exceptions. The crux of the analysis, then, is that the basin states would go some way towards the conclusion of a Nile basin treaty if they bring themselves to terms with the fact that the colonial treaties on the

\footnotetext{
${ }^{14}$ Valentina Okaru-Bisant, 'Institutional and Legal Frameworks for Preventing and Resolving Disputes Concerning the Development and management of Africa's Shared River Basins' (1998) 9(2) Colorado Journal of International Environmental Law and Policy 348-349.

${ }^{15}$ For an excellent discussions of the chronology and current status of the Nile basin treaties, see generally Okon Udokang, Succession of New States to International Treaties (1972); O Okidi, 'History of the Nile and Lake Victoria Basins through Treaties' in P P Howell,

and J A Allan (ed), The Nile: Sharing a Scarce Natural resources-A Historical and Technical Review of Water Management and of Economic and Legal Issues (1996)

${ }^{16}$ See 'The Nile: Water Conflicts' < http:// www.scienceinafrica. co.za/ 2003 /may / nile.htm> , accessed 08 April 2008; See also generally Girma Amare, Nile Issue: The Imperative Need for Negotiation on the Utilization of Nile Waters, EIIPD Occasional Papers Vol.2, No.6 (1997).

${ }^{17}$ The Nile Basin Initiative Act (2002), Preamble, Para 1
} 
Nile waters are of no legal significance and that general international law cannot go down to the extent of apportioning shared waters such as the Nile. It is such an awakening that would pave the way for a constructive negotiation that helps start from a clean slate in view of inaugurating a comprehensive Nile Basin treaty and institutional mechanism for the equitable apportionment of the common resource

\section{Divorce from the Past: The Role of Colonial Treaties and Colonial Mindset}

History of inter-state interactions in the Nile basin is replete with repeated and overlapping efforts of the European colonizers to bring the river under their respective sphere of influence aimed at achieving their imperial objectives. Thus reference to the past, though important, does not offer much towards the harmonization of inter-riparian attitudes in their interactions and joint search for a cooperative framework over the Nile issue. Arguably, therefore, some of the colonial mentalities and traits of colonial motives have remained behind after the departure of the colonial masters, and it is still apparent in the inter-state negotiations over the use of the Nile waters such that these traits continue to hamper joint efforts towards the conclusion of a basin -wide treaty regime.

Historically, the Nile was part and parcel of the colonial scramble for Africa particularly because of the realization that control of Egypt and the Suez Canal by colonial administrations depended heavily upon the possibility of controlling the Nile.

[t]here are about ten agreements dealing with consumptive use of the waters of the Nile and Lake Victoria. Prior to World War I, the treaties show Great Britain, for Egypt, as the contracting state. The United Kingdom, then the administering colonial power over Sudan, concluded an agreement with Italy (1891), Ethiopia (1902), the independent State of Congo (1906), and with Italy and France (1906). There is further agreement with Italy, signed by Britain, in 1925. Since then, Britain and Egypt signed all agreements on the Nile waters, beginning with the 1929 agreement dealing with Egyptian rights generally vis-à-vis those of Sudan, and ending with the agreements for construction and maintenance of the Owen Falls Dam achieved by Exchange of Notes between 1949 and $1953 .{ }^{18}$

Notwithstanding Belgian control of Burundi, Rwanda and Congo (now Democratic Republic of Congo (DRC)), Ethiopia's independence and Italian control of Eritrea, Great Britain had effectively controlled the Nile River

${ }^{18}$ Okidi, note 15 above, 323. 
from its origins to the Mediterranean Sea. ${ }^{19}$ Although Britain had used every possible means it had at its disposal to achieve the full control of the Nile, the more diplomatic avenue of concluding international treaties with the only independent state in the basin at the time (Ethiopia) and European powers controlling some of the then colonies provided an effective device towards that end. The most striking feature common to all the colonial treaties signed by Great Britain was the fact that in all the treaties the protection and furtherance of Egyptian interests (and colonial interests in Egypt) were the primary consideration.

It may not be that Great Britain intended so much to protect Egyptian interests per se as it did to protect its own colonial ambitions. For one thing, no colonial power like Great Britain could have failed to take note of the value of Egyptian Red Sea ports that were of central importance to Britain's colonial trade. Thus, during the colonial period, the 'Nile waters continued to be the lifeline of British colonial economic interest same as they had always been for Egypt. ${ }^{20}$ For another, the Suez Canal commanded a central strategic importance for controlling the shortest route from Europe to India- the 'Jewel of the British Crown'. Besides, the colonial policy of exploiting the huge Egyptian cotton productions for the textile mills in England was contingent upon Egyptian political stability. As Elhance noted, '[t]o a very large extent, this stability became contingent upon satisfying Egypt's growing water needs, without much regard for the interests of the other riparian., ${ }^{21}$

This colonial policy was also prompted by the desire to manipulate the Nile waters in order to soften the anti-colonial uprising in Egypt. ${ }^{22}$ The British were pretty much aware of the fact that unless they control the Nile waters, it would have been impossible to put pressure on Egyptian nationalism that was on the rise against the colonial rule. As Yacob Arsano noted, while Britain acted as a provider of the Nile waters to Egypt, 'it was naïve to believe that the British were dying for Cleopatra's Egypt, but the former was using Egypt's most sensitive resource to soothe the anti-British nationalist anger in Egypt since the end of the First World War' ${ }^{23}$ By 1923, this policy was formulated in an unequivocal manner: 'The power which holds the Soudan (sic) has Egypt at its mercy and through Egypt can dominate the Suez Canal. ${ }^{24}$ Such considerations had been behind the lopsided colonial agreements per-

\footnotetext{
19 Arun P. Elhance, Hydropolitics in the tion, The University of Zurich) (2004) Third World: Conflict and Cooperation 53. in International River Basins (1999) 68. ${ }^{21}$ Elhance, note 19 above, 68

20 Yacob Arsano, Ethiopia and the Nile: ${ }^{22}$ Yacob, note 20 above, 54. Dilemmas of National and Regional Hy- ${ }^{23}$ Yacob Arsano, 'Towards Conflict Predropoitics(Unpublished, PhD Disserta- vention in the Nile Basin' (Paper pre-
} 
taining to the utilization of the waters of the Nile. In the words of Yacob ${ }^{25}$, 'Britain made sure that all Nile related agreements benefited its own colonial interests.' It was almost inevitable, therefore, that the multitude of the colonial agreements that Britain initiated and concluded with the upstream actors 'were far from establishing a regime of reciprocal rights or providing shared benefits on the transboundary water resources. 26

The striking similarity of all the colonial agreements lies in the fact that they, rather than establishing basin wide regulatory frameworks, established precedents and informed postcolonial mindset of riparian states whose behaviour, at least partially, are modeled on the colonial era approach to the problem, and that continued to hinder fresh negotiations and agreements upon the equitable utilization of the Nile. ${ }^{27}$ The treaties of the colonial era in most cases banned irrigation, power generation and other uses of the Nile waters without the prior agreement of the Egyptian government in order to ensure the constant unreduced flow of the waters to Egypt. ${ }^{28}$ Besides, these treaties encouraged unilateralism rather than cooperative management of the common resources; indeed, the utilization of the Nile waters depicts a marked difference between the rhetoric of the river being common to the riparian while remaining private to Egypt and Sudan. As observed by Kinfe, '[t]he British stance, in more sense than one, represents the early embryo of unilateralism which still bedevils the relationship among the riparians in general and that of Ethiopia and Egypt in particular. ${ }^{29}$

Notwithstanding the departure of the colonizers and the attainment of independence by the former-colonies of the Nile basin, , the colonial era mentality is still refusing to give way to the post independence situations, as it is still lingering only to aggravate the long standing injustice relating to the utilization of the bounty of the Nile. The Egyptian leaders, beginning from the time of Nasser, adopted the concept of 'water security' from the British who had stated: 'No one can hold Egypt securely unless he also holds the

presented at the 5th Nile 2002 Conference, 1997) 491.

24 John Murray, British Foreign Minister Bureaucrat, in his Memorandum on the Political Situation of Egypt, quoted in Terje Tvedt, “The Management of Water Irrigation: The Blue Nile" in Beyond conflict in the Horn of Africa (1992) 186.

${ }^{25}$ Yacob, note 20 above, 53.

${ }^{26}$ Ibid.

27 Y A Mageed, 'The Integrated River Basin Development: The Challenges to the
Nile Basin Countries' in J Lundqvist, U Lohm and M Falkenmark (ed), Strategies for River Basin Management (1985) 155.

${ }^{28}$ Ibid, 151.

Abraham Kinfe, 'Nile Hurdles: PsychoPolitical Roadblocks to An Agreement and the Way Forward toward A Rapprochement' (2000) Occasional Papers Vol.2, No.6 (Ethiopian International Institute for Peace and Development, EIIPD) 2. 
whole valley of the Nile. The sources of the river in hostile or even in indifferent hands must always be a grave cause of danger. ${ }^{30}$

Whereas the post independence era has witnessed only one treaty- the 1959 Agreement for the Full Utilization of the Nile Waters- concluded between Egypt and Sudan, this treaty has proved, like its colonial era predecessors, to be nothing more than a continuation of the colonial policies. It is only anomalous for two downstream states with extremely marginal water contribution to the Basin, if not none, to agree for 'the full utilisation' of a river originating in and shared by eight other states. Like its colonial predecessors, it was aimed to protect the Egyptian, and, to a lesser extent, Sudanese interests. Like the colonial era treaties, it did not give any consideration to the interests of the other riparians that are equally entitled to the utilisation of the waters of the Nile. Tesfaye has rightly asserted:

Ever since the signing of the 1959 Agreement Egypt had time and again showed its inflexible stance towards the alteration of the treaty. ...It [Egypt] rather considers the 1959 and preceding agreements as unchanging and sacrosanct. In effect, in as far as Egyptians are concerned, any fresh talk on the Nile water utilization beyond the 1959 status quo must by all means be circumvented. Put another way, the bottom line to any talk and the resultant modus vivendi, if any, should first and foremost take the 1959 status quo for granted and rather discuss the possibility of acquiring additional water in the Nile Basin. ${ }^{31}$

As recently as March 2008, Egypt and Sudan maintain that the framework agreement that has been drafted by the NBI should include a clause that reads: "[n]ot adversely affect the water security of current users and rights of the Nile Basin countries." 32 It has been reported that the water security of current users referred to here is the uses established under the 1929 and 1959 treaties between Sudan and Egypt. ${ }^{33}$ Where the situation stands now, admitted the NBI, the disagreements have presented a significant hitch to the NBI processes and it needs the intervention and negotiation by the political heads of the states to expedite the process. ${ }^{34}$

\footnotetext{
${ }^{30}$ Peel, quoted in Kinfe Abraham Kinfe, ${ }^{31}$ Tesfaye Tafesse, The Nile Question: Hy'The Nile Issue: Psycho-Political Hurdles dro Politics, Legal Wrangling, Modus to an Agreement and the Way Forward Vivendi and Perspectives (2001) 79. Toward a Rapprochement' (Paper pre- ${ }^{32}$ See Daily Nation, note 12 above sented at the 5th Nile 2002 Conference, (emphasis added). 1997) 599.
} 
Yet, it needs no mention of the fact that the two treaties bind only the parties to them: -Sudan and Egypt- and should basin wide treaties be agreed, an entirely different document is needed that is based on a new equilibrium of equitable and reasonable utilisation. ${ }^{35}$ The fact that new uses are of equal importance as existing uses cannot be overemphasised. Thus the post independence (1959) agreement and the attitude of some of the riparians in the ongoing NBI process proved to be a continuation of the colonial era mentality wherein the Nile was presumably geared almost exclusively towards the fulfilment of interests of Egypt (and Sudan) .Thus the postcolonial mindset of some of the riparian states is a close imitation of that of the preindependence period that has served as a strong precedent upon which the Egyptian and Sudanese leaders modelled their post decolonization (1959) agreement on the Nile.

It is just axiomatic, therefore, that the 'colonial era mentality, subsequently inherited by the rulers of independent Egypt [and Sudan], and the resentments it has generated in the newly independent nations have continued to circumscribe hydropolitics in the Nile basin in the post-World War II era. ${ }^{\text {,36 }}$ As a result, the "current management of Nile waters is one based on the views articulated by British imperial interest in the first half of the twentieth century which were ... based on the assumption that Egypt's interests were paramount. ${ }^{37}$ Insistence upon the continuity of the prevailing situation would inevitably mean that the interests of the upstream Nile basin states would continue to play second fiddle to those of the downstream states. Such an imbalance has bred an impasse that has been hindering fresh negotiations over the allocation of the bounty of the Nile.

\section{Resolving Doctrinal Controversies ${ }^{38}$}

International law has been suffering from fluidity as regards the rules applicable to the consumptive utilization of international rivers. Against the backdrop of such ambiguity, the Nile riparian states have locked horns in their adherence to contradictory doctrines, the choice of which has heavily de-

\footnotetext{
${ }^{34}$ Ibid.

${ }^{35}$ Okaru-Bisant, note 14 above, 331.

${ }^{36}$ Elhance, note 19 above, 69.

37 J.A Allan, 'Nile Basin Water Management Strategies' in The Nile: Sharing a Scarce Natural resources-A Historical and Technical Review of Water Management and of Economic and Legal Issues (1996) 316.
}

\footnotetext{
${ }^{38}$ It is beyond the purpose and scope of this work to delve into the details of the doctrinal controversies revolving around riparains' rights over shared water resources. For the present purposes, the intention is to show that arguments emerging from varying theories have contributed not in bringing the Nile riparians together but have worked to set them apart.
} 
pended on political expediency. Needless to say, certain doctrines have become obsolete. But the tendency of adherence to them by Nile Basin states presents an obstacle that stands in the way of the formation of a new Nile Basin treaty. Of the various doctrines known to international law, two theories deserve a brief revisit here.

\section{1- The Theory of Absolute Territorial Sovereignty/ The Harmon Doctrine}

The theory follows from the assumption that a state is a master of all persons, things and circumstances existing in its territory. Accordingly, a state may adopt any measures relating to that segment of the waters flowing on its territory and freely dispose of the resource. In so doing a state consults and is guided only by its own national interests. In its bare form the theory advocates that 'an international watercourse situated in the territory of a State constitutes part of the public domain of that State and that since a State has dominium over its territory, another State acquires rights thereon only with the agreement of the first State'. ${ }^{39}$

Historically, the theory was authoritatively stated for the first time by Judson Harmon, Attorney-General of the United States, in a declaration of 1895 concerning the disputes over waters of the Rio Grande River between United States and Mexico. Invited to give his opinion on the position of the United States on the question of whether the United States was obliged to let flow to Mexico parts of the waters of Rio Grande which were diverted upstream, Attorney-General Harmon gave his famous statement:

The fundamental principle of international law is the absolute sovereignty of every nation, as against all others, within its territory... . All exceptions $\ldots$ to the full and complete power of a nation within its own territories must be traced to the consent of the nation itself. They can flow from no other legitimate source. .... . The immediate as well as the possible consequences of the right asserted by Mexico show that its recognition is entirely inconsistent with the sovereignty of the United States over its national domain. ... The case presented is not a novel one. Whether the circumstances make it possible or proper to take any action from considerations of comity is a question which does not pertain to the Department [of Justice]; but that question should be decided as one of policy only, because, the rules, principles, and precedents of international law impose no liability or obligation upon the United States. ${ }^{40}$

39 Bonaya Adhi Godana, Africa's Shared Water Resources: Legal and Institutional Aspects of the Nile, Niger, and Quoted in Stephen C. McCaffrey, The Law of International Watercourses: NonNavigational Uses (2001) 115. 
This strong statement has provided the genesis and the strength for the theory of absolute sovereignty. ${ }^{41}$ The consequence of the theory is that it allows upstream states a complete freedom of action with regard to that segment of international watercourses flowing within their territories, irrespective of any prejudice it might entail in other countries downstream. That the theory is favourable to upper-basin states and, where there are several of them, to the uppermost one needs no further comment. It is not surprising therefore that Ethiopia's aide-memoire of 23 September 1957 addressed to diplomatic missions in Cairo seems to incline towards this theory although it did not categorically adhere to it. In fact, the following aide-memore was a reaction to Ethiopia's exclusion from the negotiation process between Egypt and Sudan.

Ethiopia has the right and the obligation to exploit the water resources of the Empire...for the benefit of present and future generation of its citizens...[and]...must, therefore, reassert and reserve now and for the future, the right to take all such measures in respect of its water resources and, in particular, as regards that portion of the same which is of the greatest importance to its welfare, namely, those waters providing so nearly the entirety of the volume of the Nile, whatever may be the measure of utilization of such waters sought by recipient states situated along the course of that river. ${ }^{42}$

At the UN Water Conference held in Argentina (in 1977), Ethiopia pronounced that it is '...the sovereign right of any riparian state, in the absence of an international agreement, to proceed unilaterally with the development of water resources within its territory. ${ }^{, 43}$ Although this statement sounds stronger than its real content, it does not articulate absolutist utilization in disregard to lower riparians.

The theory of absolute territorial sovereignty has not been received well by state practice or by publicists. Foremost opposition comes from downstream states in many parts of the world whose right to the international waters will be sacrificed to the extent of the validity of the theory. So too, the great majority of writers emphatically reject the theory of absolute territorial sovereignty or the Harmon Doctrine and no support for the doctrine can be found in contemporary literature. ${ }^{44}$ Support for the theory from judicial practice is also next to none. ${ }^{45}$ Indeed, the theory is 'almost unanimously abandoned today'. ${ }^{46}$ In the context of the Nile basin, it has yet to be unanimously re-

\footnotetext{
${ }^{41}$ McCaffrey, note 40 above, 113.

${ }^{42}$ Quoted in Godana, 39 above, 35-36

${ }^{43}$ Clarke, quoted in Yacob, Supra note 19 at 55 .
${ }^{44}$ Godana, note 39 above, 36; McCaffrey, note 40 above, 123.
${ }^{45}$ Godana, note 39 above, 36.
${ }^{46}$ Ibid, 38.


nounced by the riparian states. Nevertheless, the Nile riparian states' unanimous declaration that they seek 'to achieve sustainable socioeconomic development through equitable utilization of, and benefit from, the common Nile Basin water resources ${ }^{47}$ seems to be a move towards the renunciation of the doctrine.

\section{2- The Theory of Absolute Territorial Integrity}

This theory is the polar opposite of the absolute territorial sovereignty doctrine. While the latter advocates an upper riparian's complete freedom of action in relation to international waters, the theory of absolute territorial integrity maintains that the upstream state may not do anything that might affect the natural flow of the water into downstream state. According to this theory, therefore, upper riparians of a river that start to develop their water resources more slowly than lower riparians of the river will be seriously affected as they will be prohibited from undertaking any activity that would seriously affect the flow of the river to a state or states downstream.

Indubitably, this theory has been espoused and advocated by downstream riparian states. The fact that life in Egypt has been totally dependent on the waters of the Nile for millennia prompted Egypt to claim that it has 'historical', 'natural' or 'acquired' rights. Such a claim is to find its roots in the theory of absolute territorial integrity. According to Girma,

The Egyptians, and to a lesser extent the Sudanese, favour the prior use doctrine, also known as prior appropriation doctrine which provides that 'the first user of the water acquires a definitive right to it, "first in time, first in right”. ${ }^{48}$

For fear of the possibility that Ethiopia and other upper riparians may begin to construct projects that would reduce the amount of water flowing into Sudan and Egypt, the two lower most riparians hold to this doctrine in order that the upstream states remain prevented from using the waters. The doctrine is premised on the fact that the lower riparians have long put the Nile waters to their use before the upper riparians have, and, as a result, have acquired 'historic rights' thereon. In Erlich's view, there are dual moral dimensions to Egypt's 'historic rights': 'first, Egypt has no other option to survive; and, second, Ethiopia has lived without the Nile so far and presumably can do so in

47 See Preamble, The Nile Basin Initiative Act, 2002, available at < http:// www. nilebasin.orgindex.php?option=com_docman\&task=doc_view\&gid=8>, Para 2, accessed 05 April 2008 (emphasis added).

${ }^{48}$ Amare Girma, 'Nile Issue: The Imperative Need for Negotiation on the Utilization of Nile Waters' (1997) Occasional Papers Vol.2, No.6 (Ethiopian International Institute for Peace and Development, EIIPD) 8. 
the future' ${ }^{49}$ It would come as no surprise that the doctrine of absolute territorial integrity, and its corollary, 'historic rights', has therefore been advocated foremost by lower- most riparian Egypt compared to any other riparian. But it is too much to assume that the moral dimension of the argument will lead to legal right. It has been observed that:

[t]he Egyptians' legal argument for their exclusive rights to the Nile waters is founded on precedence: Egypt has always used the waters of the Nile without restriction. ...Moreover, they argue, the idea ...was confirmed by the international agreements signed during the twentieth century. The principle of historic rights was mentioned in the 1929 Egyptian [British]-Sudanese Water Agreement and reiterated in the agreement for the Full Utilization of the Nile Waters of 1959. In fact, Egyptian (and Sudanese) exclusiveness with regard to the Nile waters was recognized by the British in all their colonial agreements. ${ }^{50}$

As Egypt has always been sensitive to the possibilities of development of the Nile by upstream states, its adherence to the doctrine of absolute territorial integrity had remained unchanged over the years. As far back as 1925, during the meeting of the Nile Commission, Egypt expressed its adherence to the theory of absolute territorial integrity on the division of the waters of the Nile among the riparians. More than five decades later, in 1981, Egypt expressed its unchanged stance in its 'Country Report' at an interregional meeting of international river organizations held in Dakar. The Report argued:

[e]ach riparian country has the full right to maintain the status quo of the rivers flowing on its territory... it results from this principle that no country has the right to undertake any positive or negative measure that could have an impact on the river's flow in other countries. ... a river's upper reaches should not be touched lest this should affect the flow of quantity of its water. ${ }^{51}$

Like the theory of absolute territorial sovereignty, the theory under consideration has been a subject of severe criticisms. It is extremist in essence and myopic in orientation. As Godana noted, 'the essential inequity of this theory resides in the fact that it allocates rights without corresponding duties. ${ }^{52}$ Neither state practice, nor the practice of international or domestic tribunals nor the writing of publicists has sufficiently supported this theory. Political statements aside, even Egypt has not been consistent in practice in its adherence to the theory. Suffice for the present purposes to mention that Egyptian agreement of 1949 to projects in upper Nile countries, such as the Owen Falls Dam in Uganda, which is a huge

\footnotetext{
${ }^{49}$ Haggai Erlich, The Cross and the River: ${ }^{51}$ Quoted in Godana, note 39_above, 39. Ethiopia, Egypt, and the Nile (2002) $6 . \quad{ }^{52}$ Godana, note 39 above, 39.

${ }^{50}$ Ibid.
} 
departure in practice from the theory of absolute territorial integrity. ${ }^{53}$ Thus the theory, like its opposite, has gone out of favour, and 'may now be considered as discarded. ${ }^{54}$

Nevertheless, it is odd to witness that insistence on this theory seems to be at the roots of the recent deadlock created in the NBI wherein Egypt and Sudan insisted upon the inclusion of a provision that has the import of maintaining the status quo of prior appropriation of the Nile waters by the two downstream states ${ }^{.55}$ That would have made the whole NBI efforts a futile exercise at best. Such a stance in itself is a bottleneck to the formation of any basin wide agreement among the riparians, but most importantly, it has played a knock-on effect by enticing the upper riparians to pay in kind. According to Yacob, adherence to the theory by downstream states of the Nile Basin has provoked the upper riparians to hold to a counter stance, wherein they hold to the principle of absolute territorial sovereignty over the waters flowing in their territories. ${ }^{56}$ As stated earlier, Ethiopian position was unambiguously enunciated at the UN Water Conference held in Argentina in 1977 in which Ethiopia pronounced the '... sovereign right of any riparian state, in the absence of an international agreement, to proceed unilaterally with the development of water resources within its territory. ${ }^{57}$ We may, however, consider this statement as a declaration which amplifies an aspect of the theory of equitable utilization because it has the basic theme of claiming equitable share.

\section{3- Current Trends towards Equity}

As the two doctrines highlighted above are in frontal clash with each other, any direct, indirect, total or partial adherence thereto in negotiations on the optimal utilization of the Nile can only set the countries apart rather than bring them to a point of agreement. Although the respective validity of the doctrines in terms of the contemporary practice of states and of international law has been called into question, the position of the Nile riparian have been, at least in theory, locked in these irreconcilable doctrines, and as such their contribution in hindering a negotiated agreement cannot be ignored.

The doctrine of equitable utilisation made its appearance in the vocabulary of many of the riparian states of the Nile Basin only in recent past, but it may well be said, to use the usual catch-phrase, better late than never. Granted, it is hoped that this new trend would provide a framework from which to work towards equity among the basin states in their respective rights and duties in the utilisation of the Nile waters.

\footnotetext{
${ }^{53}$ McCaffrey, note_40_above, 131.

${ }^{54}$ Godana, note 39 above, 39.

55 See Daily Nation, note 11 above.
}
${ }^{56}$ Yacob, note 19 above, 55.
${ }^{57}$ See Clarke, as quoted in Yacob, note 19 above, 55 .




\section{Back to the Future: Towards an Equitable and Reasonable Utilisation}

\subsection{Introducing the Concept}

The principle of equitable and reasonable utilisation of common water resources is the pillar of inter-state interaction over the uses of international waters. ${ }^{58}$ Predicated on the sovereign equality of states, this theory seeks to ensure to all basin states an access to a reasonable and equitable amount from the shared waters, but it also imposes the duties upon all riparian states to use the resource in an equitable and reasonable manner. ${ }^{59}$ It is crucial to stress that at the heart of the principle of equitable utilisation is co-riparian states' 'equality of rights, ${ }^{60}$ which means that riparian states have an equal right to use the common water resources in accordance with their needs. ${ }^{61}$

It does not necessarily imply volumetric equality of shares. As Goldberg observed, '[e]quality of rights does not mean in this context the right to an equal division of the waters but rather that each riparian has an equal right to the division of the waters on the basis of its needs, consistent with the corresponding rights of other co-riparians. ${ }^{, 62}$ Simply put, the principle of equitable utilisation rejects the exclusion of any riparian from the use of a common water resource, while providing for parity of treatment of equally pressing national needs of all the co-riparian states.

The actual dividend of a riparian from the common river thus turns upon multiple objective factors. According to Lipper, ${ }^{63}$ three general criteria must be applied for an equitable apportionment of the actual share of a riparian state:

a) examination of the economic and social needs of the co-riparian states by an objective consideration of various factors and conflicting elements relevant to their use of the water;

\footnotetext{
58 See Keith Hayward, 'Supplying BasinWide Reforms with an Independent Assessment Applying International Water Law: Case Study of the Dnieper River' (2007) 18(3) Colorado Journal of ${ }^{61}$ Ibid.

International Environmental Law and ${ }^{62}$ David Goldberg, 'World Bank Policy on Policy 633 642.See also Salman M. A. Salman, and Kishor Uprety, Conflict and Cooperation on South Asia's International Rivers: A Legal Perspective (2002) 15.

Jerome Lipper, 'Equitable Utilization' in A H Garretson, R D Hayton and C J Olmstead (ed), The Law of International Drainage Basins (1967) 44. Pojects on International Waterways in the Context of Emerging International Law and the Work of the International Law Commission' in Gerald H Blake, et. al. (ed), The Peaceful Management of

${ }^{59}$ Godana, note 39 above, 50. Transboundary Resources (1995) 155. ${ }^{63}$ Lipper, note 60 above, 45.
} 
b) distribution of the waters among the co-riparians in such a manner as to satisfy their needs to the greatest extent possible; and

c) accomplishment of the distribution of the waters by achieving the maximum benefit for each co-riparian consistent with the minimum of detriment to each.

It is of paramount importance to stress that the application of the principle of equitable utilization is a process that heavily reposes on the amount of confidence among riparians. Indeed, it is 'a dynamic process, which depended heavily upon active cooperation between states sharing freshwater resources. ${ }^{64}$ Such a cooperative atmosphere among riparians results from knowledge of, inter alia, data and information concerning the watercourse and its provision of prior notification to other states of new uses that might affect them. ${ }^{65}$

Be that as it may, the equitable utilization theory is also contingent upon other objective and specific factors. Under the 1997 Watercourse Convention, an illustrative (non-exhaustive) list of seven relevant criteria is provided: ${ }^{66}$

a) Geographic, hydrographic, hydrological, climatic, ecological and other factors of a natural character;

b) The social and economic needs of the watercourse States concerned;

c) The population dependent on the watercourse in each Watercourse State;

d) The effects of the use or uses of the watercourses in one watercourse State on other watercourse States;

e) Existing and potential uses of the watercourse

f) Conservation, protection, development and economy of use of the water resources of the watercourse and the costs of measures taken to that effect;

g) The availability of alternatives, of comparable value, to a particular planned or existing use.

At this juncture, it is important to note that there is no preferential treatment attached to the order of provisions of the criteria listed under Art 6 of the Watercourse Convention. One criterion can be the most important consideration in one context while other criteria may take precedence over the others in other circumstances. The bottom-line is that a factor (criterion) must indeed be relevant as an aid in the determination or satisfaction of the social and economic needs of the co-riparians of the basin. Once this threshold is met, it is not possible to attach a fixed weight to a singular criterion in all cases. The relative weight of a given relevant factor turns upon its merits relative to all the other factors at a given point in time. ${ }^{67}$ In the final analysis, 'no other fac-

\footnotetext{
${ }^{64}$ McCaffrey, note 40 above, 345.

${ }^{66}$ See Art .6 (1) (a-g).

${ }^{65}$ (Id: 343).

${ }^{67}$ See Water Convention, Art 6 (3).
} 
tor occupies a position of pre-eminence per se with respect to any other factor. ${ }^{68}$ Some factors may even be irrelevant in a given scenario at a given time for the determination of a case at hand. ${ }^{69}$ Under the Watercourse Convention 'all relevant factors are to be considered together and a conclusion reached on the basis of the whole ${ }^{70}$ in the determination of what is a reasonable and equitable use in a particular case. Additionally, the Watercourse Convention clearly guards against temptations to attach a special weight to a given use, ${ }^{71}$ and provides that in cases where conflict of uses occurs among the riparians, it instructs to attach 'special regard...to the requirements of vital human needs, ${ }^{, 72}$ presumably drinking and sanitation.

Apart from its codification in the Watercourse Convention, the principle of equitable utilisation enjoys an overwhelming support of scholarship and state practice such that 'nearly all international accords regarding international rivers are based on this principle. ${ }^{73}$ The 1966 Helsinki Rules (although not binding ${ }^{74}$ and the 1994 International Law Commission's Draft Articles (nonbinding) ${ }^{75}$ had already solemnly espoused the principle before its eventual incorporation into the Watercourse Convention. Historically, the theory of equitable and reasonable shares has been recognized in China and India for many centuries and has acquired prominence over the past 500 years with the development of the nation state. ${ }^{76}$ It seems that the principle of equitable and reasonable use is part of international custom. ${ }^{77}$ As such, its inclusion in Art 5 of the 1997 Watercourse Convention is a codification of international custom rather than a progressive development of rules of international law regarding non-navigational uses of international watercourses. ${ }^{78}$

Notwithstanding earlier debates as to the applicable theory in the Nile basin, there seems to be a change of heart among the riparian states. In their recent

\footnotetext{
${ }^{68} \mathrm{C}$ J Olmstead, et al, 'Helsinki Rules on $\left.\right|^{75}$ See 'Draft Articles on the Law of the the Uses of the Waters of International Non-Navigational Uses of International Rivers' in A H Garretson, R D Hayton Watercourses, Arts 4 and 5. and C J Olmstead (ed), The Law of In- ${ }^{76}$ Erlich, note 49 above, 7. ternational Drainage Basins (1967) 779 785.

69 Ibid.

${ }^{70}$ Art 5 (3).

${ }^{71}$ Art $10(1)$.

${ }^{72}$ Art 10 (2).

${ }^{73}$ Erlich, note 49 above, 7.

${ }^{74}$ See ' The Helsinki Rules on the Uses of the Waters of International Rivers,' Adopted by the International Law Association at the fifty-second conference, held at Helsinki in August 1966, Art IV.

77 See Richard Paisley, 'Adversaries into Partners: International Water Law and the Equitable Sharing of Downstream Benefits' (2002) 3 Melbourne journal of international law 280283.

${ }^{78}$ It must be noted that the (1997) Water Convention explicitly states that it is an embodiment not only of progressive development of international water law but also of codification of an exiting custom. See Preamble, Water Convention, Para 4.
} 
statements, an Egyptian diplomat and Ethiopia's Prime Minister, have stated their adherence to the theory of equitable and reasonable utilization of the waters of the Nile. The statement of Egyptian former Ambassador to Ethiopia, Marwan Badr, given on 7 August 1998 is instructive in this regard:

Egypt recognizes that each state has the right to equitable utilization of its waters in accordance with international law. Egypt further recognizes that existing water agreements do not hinder the utilization of the Nile waters by any of the riparian states. ${ }^{79}$

This theory has been well received in Ethiopia as well. This can be discerned from the recent statement of the Ethiopian Prime Minister, Meles Zenawi:

What we basically need is to deal with the Nile basin as a single region with shared natural resources. If we take this as a basis for dealing with the Nile issue, we will be able to devise better ways to achieve the maximum benefit from its waters. ${ }^{80}$

The biggest merit of the theory is that it takes into account both the current and future water needs of the riparians and is elastic enough to accommodate changing set of circumstances. A state's regime of utilization that is equitable vis-à-vis its co-riparians today may not be so next year. As McCaffrey noted, a 'new use in one state may change the equitable calculus as among all riparians and therefore should be the subject of notification, consultation, and if necessary, negotiation. And this is true whether the new use is made by an upstream or downstream state... ., 81

\subsection{Variants of Equitable Utilisation: Towards Application}

Conceptually it is important to distinguish between two variants or modes of application of the principle of equitable utilization. The shared uses variant refers to the classical apportionment method, and it is usually achieved through a treaty among the basin states that allocates the dependable flow of wet water of a river among the riparian states, where right to 'water qua water' is created. ${ }^{82}$ But each state enjoys complete freedom of action with respect to the choice of the manner of utilization of its quota, ${ }^{83}$ presumably, with the major caveat that no state can have the right to cause a significant harm to its neighbors through its usage of the common waters.

\footnotetext{
${ }^{79}$ Quoted in Robert O Collins. 'The In- ${ }^{80}$ Ibid. scrutable Nile at the Beginning of the New Millennium’ available at < http:// www.history.ucsb.edu/faculty / Inscrutable \%20 Nile1.pdf.>, accessed 16 December 2007(emphasis added.).

${ }^{81}$ McCaffrey, note 40 above, 345.

${ }^{82}$ Wolf Quoted in A Dan Tarlock, and Patricia Wouters, 'Are Shared Benefits of International Waters an Equitable Appor-
} 
The second variant of equitable utilization, called shared benefits principle, springs from welfare economics, and its gist is that water is a scarce resource that can be put to alternative uses but that in water sharing processes among the riparians of a given water states must ensure that water is put to a use that is most valuable as compared to the other uses. ${ }^{84}$ The implication in many cases would lead to a situation where 'some nations forgo the actual use of wet water but are entitled to monetary compensation for allowing other states to put the water to its most efficient use. ${ }^{85}$

In the NBI discussions, references have been made to the principle of equitable utilization but it yet to be seen if the states are ready to commit themselves to the shared benefits variant of the principle. Indeed, the NBI itself started off with a participatory process of dialogue among the Nile riparian states that resulted in their agreeing on a shared vision-to 'achieve sustainable socioeconomic development through the equitable utilization of, and benefit from, the common Nile Basin water resources. ${ }^{86}$

Due to the usage of the word 'benefits' in the NBI processes, it is instructive to make an overview of the advantages and demerits of the two variants. At one level, the difference between the two variants appears to be little more than semantics. It could be argued that the object of any equitable distribution of an international river being to ensure that all riparian states receive 'water justice', and since 'water justice' can be obtained equally by sharing the use of wet water or by monetary compensation, the dichotomy is a distinction without a difference. ${ }^{87}$

Yet, such a line of argument comes out of a lack of deeper insight into problems associated with the practical application of the two variants of the principle. It may be pointed out that at least three concerns are associated with the 'shared benefits' variant of the principle. ${ }^{88}$ Firstly, upstream headwater states are usually less fortunate than the usually wealthier downstream states, and such is the case in the Nile Basin. As a result, they may be tempted into accepting short-term benefits at the expense of forgoing their future uses. ${ }^{89}$ Secondly, shared benefits may not directly address problems of poverty alleviation, and they usually fail to benefit those in the watershed of origin. ${ }^{90}$

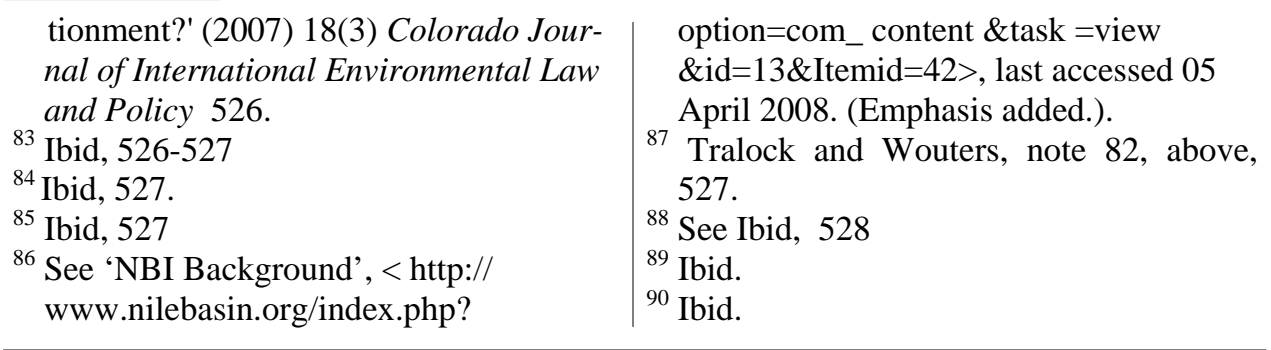


Thirdly, benefit sharing runs the risk that aquatic ecosystem integrity may not be adequately addressed, and the bio-system of the basin may be negatively affected. ${ }^{91}$ The problems, as they are, may not be insurmountable but they must be carefully addressed. It can only be hoped that the ongoing negotiation over the cooperative utilization of the Nile waters will carefully address these and other related concerns.

\subsection{Equitable Utilisation vis-à-vis No-significant Harm Rule}

The principle of equitable utilisation and the 'no-significant harm' rule have been vying for recognition for a long time. Normally, the interplay of the doctrines of equitable utilisation and that of preventing 'significant harm' in the utilization of common waters are presented as a warring company. Historically, the no significant harm rule emerged before the principle of equitable utilisation. It regulated a whole range of neighbourly relations, especially transboundary harms attributable to the commission or omission of a neighbouring state.

The origin of the 'no harm rule' may be traced to the Roman law maxim: sic tuo utere ut alienum non laedas (use your property in such a way as not to harm others). ${ }^{92}$ It was originally based on the concept of restrictive enjoyment of one's own property, or limited and regulated proprietary rights subject to the prevention of harm to one's neighbours. ${ }^{93}$ Put in the context of inter-state relations, it implied that neghibouring states 'are not allowed to use or to tolerate the use of their territory for causing damage to their neighbours. ${ }^{94}$

Contrary to the rule of 'no-significant harm' which aspires to regulate the overall relations of neighbouring states, the principle of equitable utilisation is limited in scope to the regulation of inter-states' non-navigational activities on international watercourses. ${ }^{95}$ Indeed, its emergence was prompted by the limitations of the 'no-significant harm' rule in relation to allocation of international watercourses. The 'no-significant harm' fails to provide adequate rules for the resolutions of controversies over 'allocation issues on fully-used or over-used international watercourses, or would have done so in an [un] equitable way...by giving complete priority to existing activities and by prohibiting the development of new or the extension of existing uses. ${ }^{\text {,96 }}$

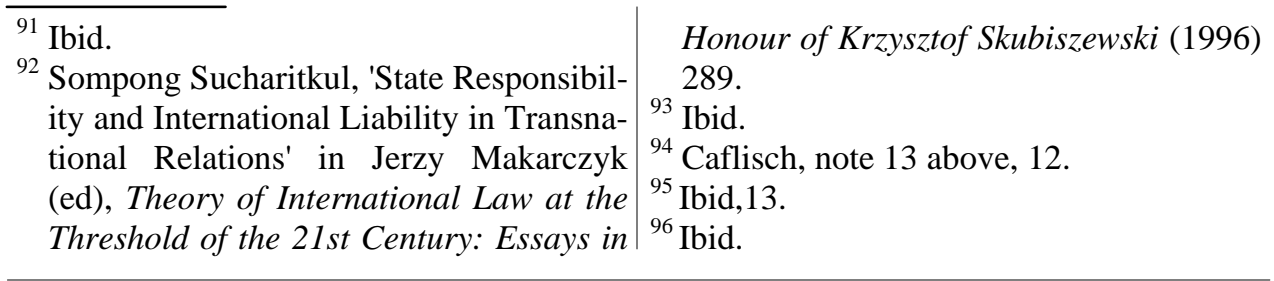


According to Caflisch, the no-significant harm rule has strived to play two related roles pertaining to the law of international rivers. ${ }^{97}$ First, it seeks to provide guidelines in the allocation of the rights of shared water basins, and, second, it is also of crucial relevance in the area of environmental protection. While it has continued to hold sway in relation to environmental considerations, its water allocation utility has waned in recent years. ${ }^{98}$ This is because most international water basins are fully used or overused today and an attempt at a new use by a riparian state would result in causing harm to the existing uses. The effective result of this no-significant harm rule is to maintain the status quo. Considered in the context of the Nile basin, where the water is already fully used and new upper riparian attempt to put the waters to imminent new uses, ${ }^{99}$ the application of the 'no-significant harm' rule would deny the upper riparians any possibility of developing or expanding their use of the Nile waters. ${ }^{100}$

It was such a shortcoming associated with the no-significant harm rule that has brought into focus the need for clarification of the interplay of this doctrine with the principle of equitable utilisation. It is sterile to state that the prevention of any harm in a basin such as the Nile where ten states share the common waters is a matter of impossibility. The question that poses itself is as to which one of the two - the principle of equitable and reasonable utilisation or of no significant harm rule-takes precedence in the event that the two happen to contradict each other.

In situations where an upstream state commences a new project that would otherwise be a reasonable and equitable use of a common international river, the new use upstream would almost inevitably result in the reduction of the quantity or quality of the water that flows downstream. Such a reduction would inevitably cause harm to the pre-existing uses of the downstream state by diminishing the quantity or quality of the water owing to the new upstream use.

Under the doctrine of equitable and reasonable utilisation, the fact that there had been prior uses made of the common waters by some of the riparian would be one of the considerations in arriving at the equitable and reasonable allocation of the common waters. A use by a riparian may cause harm to the pre-exiting uses by another riparian. A choice must be made between the applications of the two competing principles.

\footnotetext{
${ }^{97}$ Ibid, 12.

98 Ibid.

${ }^{99}$ Ashok Swain, 'Managing the Nile River:

The Role of Sub-Basin Co-Operation' in ${ }^{100}$ Caflisch, note 13 above, 13. Manas Chatterji, Saul Arlosoroff, and

Gauri Guha (ed), Conflict Management of Water Resources (2002) 145146-152.
} 
Historically, the need for clarification of the interplay of the two principles arose much earlier in the context of the 1966 Helsinki Rules. Thus the International Law Association considered that 'the principle of equitable and reasonable utilization should be the guiding principle... [wherein the nosignificant harm] rule was one among the series of elements to be considered for determining whether a given use was "equitable and reasonable".,101

It has been observed that there exists unanimity of opinion among scholars that, in the event of conflicts among principles, 'the most fundamental principle of international water law is that of equitable utilisation. ${ }^{102}$ In short, the principle of equitable utilisation takes precedence over the no significant harm rule. If it were otherwise, the resultant situation would be to freeze the development of many upper riparian states to international basins, and this is perhaps more so in the Nile Basin than anywhere else. An immediate result of the precedence of equitable and reasonable utilisation over the nosignificant harm would be to lay to rest the 'prior appropriation' doctrine that has been overly emphasised by the lower riparians of the Nile basin. Thus, the rules of international water law do not approve of downstream states' foreclosure of upstream new projects by demonstrating that the later development would cause it harm. ${ }^{103}$

During the preparation of the draft of what was to later become the Watercourse Convention, the International Law Commission commented that:

[prima facie], utilisation of an international water course is not equitable if it causes other watercourse states appreciable harm. ... The Commission recognizes, however, that in some instances the achievement of equitable and reasonable utilisation will depend upon the toleration by one or more watercourse states of a measure of harm. ${ }^{104}$

Applied alongside with the principle of equitable and reasonable utilisation, thus, the no significant harm rule imposes the duty of due diligence on the riparian states that start to put the common waters to a new or more use than had been the case. The due diligence duty goes beyond requiring a state to abstain from causing a harm to the other riparians and includes a positive duty to 'take all appropriate measures to prevent the causing of significant harm to other watercourse States. ${ }^{105}$ It has been observed that events that should be prevented in a state's territory could be lawful activities in the par-

\footnotetext{
${ }^{101}$ Caflisch, note 13 above, $13 . \quad \quad{ }^{103}$ Ibid.

102 Stephen C McCaffrey, 'The Law of In- ${ }^{104}$ See Report of the International Law ternational Watercourses: Some Recent Developments and Unanswered Questions' (1989) 17(3) Denver Journal of International Law and Policy 509. Commission on the Work of its Fortieth Session, 43 U.N. GAOR Supp. (No. 10), U.N. Doc. A/43/10 (1988), pare 84.
} 
ticular state's territory, but suffice for it to cause the state's international liability so long as they entail a significant harm in a neighbouring state. In the end, everything boils down to the requirements of mutual empathy among the riparian and the search for 'glasses half-full'. ${ }^{106}$ There is a compelling need to maintain a delicate balance, and departure to either end from such an equilibrium is equally prejudicial.

\section{Back to Point of Departure: The Water Convention and Basin-Specific Arrangements}

The analysis of the interplay of the principle of equitable and reasonable utilisation and the no-significant harm rule would take us back to our initial observation that much has to be achieved via basin-specific arrangements such as the NBI. The rules of general international law provide general framework within which basin-specific rules can be made. But, given the adherence of the states to polarised positions, and the concern for sovereignty being still at play, it would take a long time for general international law, not least the Watercourse Convention, to play a major part in the resolution of water allocation in the Nile Basin. Indeed, some have doubted whether the Watercourse Convention would ever become truly operational. ${ }^{107}$

The adoption of the Watercourse Convention has seen an expressed suspicion, and even rejection, from the Nile riparians. Ethiopia complained of the lack of balance between the rights of downstream states and those of upstream states, and retorted that the Working Group that drafted the Watercourse Convention had made 'no serious desire to accommodate' the interests of the upstream states, 'particularly [those of] .... a developing country such as Ethiopia. ${ }^{, 108}$ Rwanda pointed out that the Watercourse Convention lacked regard for sovereignty which it considered a 'sacrosanct principle' in treaty making processes. ${ }^{109}$ Burundi outrightly rejected the Watercourse Convention and voted against it alongside China and Turkey. Egypt, Ethiopia, Rwanda and Tanzania have abstained in the voting process and have not signed it to date. ${ }^{110}$ The Democratic Republic of Congo, Eritrea, and Uganda were absent and did not vote, and have not acceded to the Watercourse Convention subse-

\footnotetext{
${ }^{105}$ Art 7 (1), Watercourse Convention. See ${ }^{108}$ Aaron Schwabach, "The United Nations also Sucharitkul, note 92 above, 289.

${ }^{106}$ I borrow this phrase from Elias N Stebek, 'Eastern Nile at Crossroads: Preservation and Utilization Concerns in Focus' (2007) 1(1) Mizan Law Review 58. Convention on the Law of Nonnavigational Uses of International watercourses, Customary International Law, and the Interests of Developing Upper Riparians' (1998) 33 Texas International Law Journal 275-276.

${ }^{107}$ Caflisch, note 13 above, $16 . \quad 109$ Ibid, 276-277.
} 
quently. The only two Nile basin states that voted in favour of the Watercourse Convention were Kenya and Sudan, and their ratification is yet to come. That leaves the Nile basin in a desperate situation where any inter-state regulatory framework is utterly absent.

Consequently, the hope of establishing a legal and institutional mechanism of inter-state cooperation over the management, utilisation and development of the Nile waters almost entirely depends on the success of the NBI processes. A regulatory framework that is specific to the basin states should soon be put in place and an effort to that end must tackle a huge task of balancing differing conceptions of sovereignty, the competition between equitable and reasonable utilisation and the no-significant harm rule and the apportionment of common waters for current and future uses of the riparians which in turn demands the accommodation of competing priorities of the Nile Basin states. Achieving such an objective is a task of monumental proportions but much depends upon the level of political will to avoid mutual suicide.

\section{Towards an Attitudinal Change: The Duty to Negotiate in Good Faith}

The attitudes of the Nile riparian states depict unique features that are contributing to the anarchic state of affairs in the Basin. The White Nile riparian states are known for their reticence and ambivalence in the move towards a negotiated agreement over Nile waters utilization. Until recently, their participation in the negotiations has been minimal .

This attitude is attributable to a variety of factors. The upstream states of the White Nile contribute just a modest share to the Nile, and the consequent gains from the agreed legal frameworks that may come about may seem of minimal significance to them than to the lower riparian and upstream states of the Blue Nile. Thus they may not have much incentive to spend much resource in the search for a negotiated agreement. Their relatively lesser dependence on the waters of the White Nile basin might lie behind such states' behaviour as well. Located as they are in the humid equatorial zone with a relatively reliable rainfall and water sources outside the Nile basin, the equatorial riparians have, to date, a minimal dependence on the waters of the Nile. ${ }^{111}$ Besides, the gains that would accrue to them (from a basin-wide agreement) are so uncertain that they were not hitherto willing to risk their relationships with Egypt. ${ }^{112}$

\footnotetext{
${ }^{110}$ See The African Water Page < http://www.africanwater.org/UNPressWater.htm>, last accessed 08 April 2008.

${ }^{111}$ Tesfaye, note 31 above, 99.
} 
Eritrea, a late comer as the newest state in the Basin, maintains an observer status to date, and is not actively committed to the NBI process. The major Blue Nile upper riparian and major contributor of the waters of the Nile, Ethiopia, has for a long time been a partner without a voice. It maintained an observer status both in Undugu and TeccoNile. To use comments from one of the external assessors of this article "UNDUGU was an informal forum spurred by Egypt which sometimes raised issues (regarding the Nile at the foreign ministers meeting of the OAU" while Hydromet and TECCONILE were the formal cooperative forerunners to the NBI.

Egypt has always sought to 'dominate rather than coexist with the Nile Valley."113 It almost invariably has always preferred the 'do-it-alone' avenue than concerted efforts to develop the basin waters. The construction of the Aswan High Dam, completed in collaboration with Sudan, seems to present an exception, but even that was a project constructed to serve more of Egyptian interests than those of the Sudanese. Egypt saw the importance of using Sudanese land along the common border to build the dam close enough to be monitored and controlled from the Egyptian side. As is well known, the catastrophic human cost of the dam in the form of forced evictions of indigenous populations from their ancestral land on which the Aswan High Dam was built was borne almost solely by Sudan. And in part, it was partly a project they imposed on the only other partner (Sudan) that was in a weaker bargaining position then as it is now.

To date, Egypt is known for its propensity to resort to armed responses to perceived or real hydraulic works on the Nile that would in the slightest way reduce the amount of waters reaching the Aswan. Thus the internal attitude of the countries of the basin is marked either by one of indifference, mutual insecurity or silence and this variation in the levels of enthusiasm for basin wide framework encourages the maintenance of the status quo and unilateralism.

It must be stressed that there are rules of international law that require a state to negotiate in good faith with the aim of reaching an agreement. ${ }^{114}$. In the negotiations of water basin agreements, failure to negotiate in good faith, or, alternatively, obstructing the move towards the negotiated legal and institu-

\footnotetext{
${ }^{112}$ Ibid..

113 Elhance, note 19 above, 75.

${ }^{114}$ See Watercourse Convention, Arts 3(5), 4 (2), 8 (1), 17 (1) and (2); See also Stephen E. Draper, 'International Duties and Obligations for Transboundary wa-
}

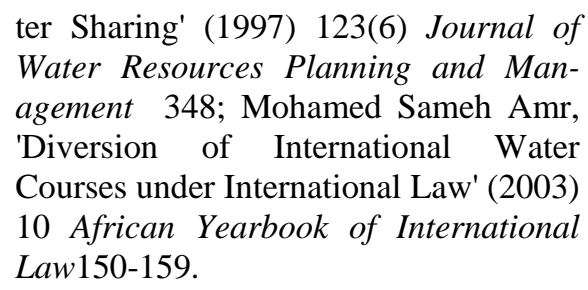
Water Resources Planning and Management 348; Mohamed Sameh Amr, 'Diversion of International Water Courses under International Law' (2003) 10 African Yearbook of International Law150-159. 
tional framework is in itself a culpable conduct. More importantly, such an obstructive conduct of a state would almost inevitably cause significant harm to other basin states. Moreover, it may lend a hand to unilateral actions of the common river and continue to breed mutual mistrust among the basin states. On all of these counts, all of the Nile Basin states can be considered suspects, and a change of such an attitude and the need for complete good faith in intra -basin negotiations is long overdue. It would not be to assume too much to state that the current intransigence of the downstream riparians in the NBI process is a continuation of the same attitude.

\section{Conclusions}

As the old adage has it, when the elephants fight, the grass gets trampled. While states of the Nile basin have engaged in legal and doctrinal wrangling on the way to basin wide agreement, each day that passes before the treaty is ratified imposes a heavy but avertable cost on the lives, economic, security and environmental wellbeing of a tenth of the African population that inhabits the Nile Basin. This paper presents a humble effort to identify the causes that hinder or slow down the process of treaty formation over the allocation of the Nile waters among the riparians. Obviously, misconception of these causes leads to misdiagnosis of the nature of the problem, which in turn leads to the mismatch of response that perpetuates conflict and suffering in the Basin. Such a situation is akin to picking ants from one's body while standing on an anthill.

This study has identified triple blockades that hamper the path to the basin wide agreement in the Nile Basin that the NBI has to deal with. The basin suffers from a legal ambiguity, doctrinal controversies and problems of good faith on the part of the states. It is with the removal of these obstacles that the NBI efforts would come to fruition in the establishment of legal and institutional mechanisms and the eventual allocation of the Nile waters in an equitable and reasonable manner.

The impending treaty must be able to establish the substantive and procedural safeguards of the rights and duties of the states vis-à-vis other riparians of the basin. Sufficient and clear mandate must be entrusted to the Nile Basin Commission that would eventually replace the NBI. Success or failure of the impending treaty regime depends on the degree to which it incorporates clear guidelines and institutional arrangement for the resolution of disputes that may ensue from time to time. The impending treaty would do well, therefore, by making provisions that take into account, inter alia, the needs of each riparian country, the yield of the river, current uses and new projects. Much of the prospect of success of the NBI ultimately depends upon the political will 
and good faith put in the transition through the temporary NBI mechanism to the permanent Nile Basin Commission. It must be acknowledged that the Nile riparians do not have viable alternatives to the joint management and equitable utilisation of the Nile waters, and the choice is one of sailing together or sinking together. Time is running out, and so is water. 